\title{
Are Hybrid Cars A Good Buy?
}

Anne Macy, West Texas A\&M University, USA

\begin{abstract}
This case examines the benefits and costs of buying a hybrid car. Students examine the car purchase decision along with depreciation rates and the long-term value of hybrid cars, while they calculate the benefits and costs of the various hybrid vehicles and their comparable sister cars. Secondary issues include an examination of the trade-in value for non-hybrid cars and the horsepower and greenhouse gas emission differences between hybrid and their sister cars. Furthermore, students will examine whether or not the federal tax credit for hybrids should be reinstated.
\end{abstract}

Keywords: Breakeven analysis, payback period, depreciation, and personal finance.

\section{INTRODUCTION}

asoline prices are at historic highs and many consumers are searching for ways to cut back on transportation spending. Hybrids offer an immediate solution. However, the solution comes at a higher purchase price. Plus, the long-term record of hybrid cars is not established. Students, in the role of Matt, examine the trade-off between the premium for hybrids and the gain in fuel economy. Students calculate the breakeven number of years for each car under different gasoline prices. Students learn that not all of the vehicles are as fuel efficient or cost efficient as one would think for a hybrid. During the evaluation process, students calculate the rate of deprecation of the hybrid cars and their sister cars. The results show that while hybrids do depreciate slower, they do depreciate and a used hybrid might be a better option. Matt also must decide if he should loan money to a customer to expand his car lot to sell hybrids. In this decision, Matt must consider that the trade-ins for hybrids are large, gas inefficient vehicles that have a low resell value. Finally, Matt must consider the long-term market for hybrids versus alternative technologies, such as fuel cells and six speed transmissions.

\section{DINNER}

Chelsea and Matt are a young, married couple just out of college. They are both working in their first jobs and saving everything they can for a down payment on a house. Chelsea works in the marketing department at the local soft drink distributor. Matt is a loan officer at a local bank. Matt had started at the bank as a teller in school and was promoted upon graduating last year. Chelsea found her job after interviewing with the distributor at the university's job fair.

Matt and Chelsea met while on the same team in a management class. The project was a SWOT analysis of Sony. After dating for a little over a year, the couple married at the campus chapel a week after graduation. While they don't have a lot of extra money, Chelsea and Matt try to go out to eat each Friday. It is a good time to rehash what happened during the week at work. It is Matt's night to pick the restaurant. Chelsea doesn't even have to ask; they are going to the steakhouse. After ordering, the couple begins to discuss their weeks.

Chelsea laments that the high gasoline prices are really starting to cut into their plans. The distributor is on the other side of town, a 30-minute drive from the apartment. She is having to fill the car tank twice a week at $\$ 60$. Plus, she has to drive to visit with customers and help them install promotional displays. It really starts to add up. Matt agrees but wonders if Chelsea could get her company to pay for the gas she uses when driving to customers. She is reluctant to ask; as a new employee, she doesn't want to rock the boat. Maybe she will see what others are doing to keep costs down. 
Matt mentions that he has a potential new loan customer, Kurt Miller, a well-known local entrepreneur who owns one of the car lots in town. Kurt always has a new deal. This one involves expanding his lot to include more hybrid cars. Demands for hybrids are high and they sell at a premium compared to the regular non-hybrid cars. To do the expansion, Kurt would need an extension on his line of credit to fund expanding the lot and increasing the inventories of the hybrids and used cars that he would get as trade-ins. Matt wants this customer, but he also knows that he can't make any major mistakes with loans. Some of Kurt's endeavors have worked out well, like the coffee shops inside the gas stations, while others, like the technology training stores, did not.

Chelsea is intrigued. Maybe while Matt is researching hybrids, he could see if they should buy one. Chelsea encourages Matt to contact Kurt and tell him he is going to begin the analysis. If it works, it would be Matt's first big client.

\section{HYBRID CARS}

Hybrids are cars that combine combustion engines running on fuel with electric motors in order to save on fuel and reduce greenhouse emissions. While the electric motors and batteries cost more, the extra cost can be made up in reduced fuel cost from the fuel savings. The savings come from three main areas: 1) The electric battery is charged from the waste energy of breaking, thus recapturing waste energy and usage. The battery charges itself while idling and breaking. 2) The electric motor will shut down the internal combustion engine when idling or in low output. The electric motor will then restart the engine when the gas pedal is engaged. 3) Finally, the electric motor allows a smaller size engine with less power because it shares some of the work with the motor.

Matt is excited. Hybrids seem great and they are good for the environment. He knows that they sell at a premium but maybe the premium is worth it. As he is researching, he learns that because the electric motor is charged from stopping, hybrids are more cost-effective for drivers who drive a lot and do a lot of stopping and starting. Thus, the hybrid premium can more easily be recouped in large city driving where the driver is in heavy traffic that involves starting, stopping, idling, and then starting again. This means that city buses which are on the road all day and stop, idle and start every five to ten minutes are a good example of a vehicle that really benefits from the hybrid engine. Taxis are another vehicle that can recoup the extra costs.

Most of the articles that Matt reads focus on the premium. He finds that the automobile industry considers three years to be the breakeven point for any new car technology, not just hybrids. This means that consumers will pay a premium if they can recoup the costs within three years in other savings or in performance increases.

Matt had read that hybrids reap a tax break; maybe that would offset the extra cost. Matt checks the Internal Revenue website and learns that the tax breaks were phased out during 2005 and 2006 and ended in 2007.

While most of the information Matt finds is positive on hybrids, he does find some worrisome information. Hybrids have a more complicated technology than a regular vehicle. Because not all mechanics have worked on hybrids, an owner would most likely have to use the dealership for repairs. Because there is not a long track record on hybrids, most manufacturers offer longer warranties then the comparable non-hybrid vehicle. The warranties are usually 80,000 to 100,000 miles. In order to increase fuel savings, many hybrids have lower horsepower. This has been upsetting to some owners who don't believe that the vehicles handle as well as non-hybrids do.

Matt was intrigued by the fuel efficiency of the vehicles. He went to the joint Department of Energy and Environmental Protection Agency (EPA) website on fuel economy (http://www.fueleconomy.gov/) and looked at the information. He learned that consumers may not realize the actual miles per gallon figures. The fuel economy figures are averages under good driving conditions. Instead, most vehicles get $15 \%$ fewer miles per gallon (mpg) than the official figures from the EPA. For hybrids, this is a larger variation because the miles per gallon are higher. If a vehicle states that it gets $20 \mathrm{mpg}$, a driver will probably get closer to $17 \mathrm{mpg}$ and if a vehicle gets $45 \mathrm{mpg}$, a driver will probably get closer to $38 \mathrm{mpg}$. When starting at a mpg of 20 , the decrease is only three mpg; but at a higher initial value, the decrease is seven mpg. 
Because fuel economy is calculated as city driving and highway driving, it can be hard to know what a customer could expect for fuel usage. Matt learns that the standard method is to assume two-thirds city driving and one-third highway driving. Plus, the average mileage is 15,000 per year.

The greenhouse score is a number between 0 and 10, with 10 being for vehicles with the least amount of greenhouse emissions. The hybrids are supposed to have less emissions, so their numbers should be higher.

Matt knows that another major expense of owning a car is depreciation. Cars depreciate the moment they leave the lot. Some cars depreciate faster than others. Matt wonders what the depreciation rate is for hybrids. There seems to be a large demand for hybrids and a limited supply, thus keeping up the price of the hybrids. However, if manufacturers increase production of hybrids, the shortage will decline and deprecation rates might rise.

Matt remembers that Kurt planned on taking trade-ins for the hybrids. However, if demand for cars is changing from gas guzzlers to hybrids, Matt wonders who will buy the trade-ins. For families buying a hybrid to replace a vehicle, they would most likely trade in the least fuel-efficient car. Matt researches this topic and learns that many hybrid dealers are not taking trade-ins or only at very reduced values because of the over-supply of nonfuel efficient cars.

Matt decides to create some tables on what he has learned. He uses the Edmonds website (http://www.edmunds.com/) to find the base prices of the hybrids and its closest non-hybrid comparable car. His findings for 2008 vehicles are in Table 1. The differences between the prices are amazing, one being that the prices are of base price. The hybrids tend to come with some features as standards instead of as options. Adding in the options would increase the price of the non-hybrid by about $\$ 1,000$. When he calculates the breakeven time for the vehicles, he will include the $\$ 1,000$. For the gas price, Matt decides to do it at $\$ 2.50, \$ 3.50$ and $\$ 4.50$ a gallon of gasoline.

Matt also decides to investigate the depreciation rate of the cars. He chooses the five vehicles that have three years of prices: Ford Escape, Lexus RX, Mercury Mariner, Toyota Highlander and Toyota Prius. The best selling hybrid vehicles are Honda and Toyota. Table 2 summaries Matt's findings.

Hybrids are only one possible solution. As Matt is researching hybrids, he finds that just switching from an automatic to a manual transmission will save about $17 \%$ in fuel usage. Researchers are working on various alternatives, such as the fuel cell and a six-speed transmission. Matt wonders if the hybrid will be able to compete with these new technologies when and if they come to market.

Matt decides to go home and share with Chelsea all that he has learned. He knows that she will want to know if a hybrid is worth the extra price and if so, which one they should buy. Plus, he needs to decide if he will loan the money to Kurt for his expansion. 
Table 1: Comparison Information of Hybrid and Non-Hybrid Versions of Similar Vehicles

\begin{tabular}{|c|c|c|c|c|c|c|}
\hline Vehicle & Make & Base price & Horsepower & $\begin{array}{c}\text { Greenhouse } \\
\text { Score }\end{array}$ & City $\underline{\text { MPG }}$ & $\begin{array}{c}\text { Highway } \\
\text { MPG }\end{array}$ \\
\hline Chevrolet & Malibu Hybrid & 23640 & 164 & $\frac{1}{8}$ & 24 & $\frac{32}{32}$ \\
\hline Chevrolet & Malibu & 19900 & 169 & 7 & 22 & 30 \\
\hline Chevrolet & Tahoe Hybrid & 49590 & 332 & 6 & 21 & 22 \\
\hline Chevrolet & Tahoe & 34630 & 295 & 4 & 14 & 19 \\
\hline Ford & Escape Hybrid & 27445 & 155 & 8 & 34 & 30 \\
\hline Ford & Escape & 20140 & 153 & 6 & 20 & 26 \\
\hline GMC & Yukon Hybrid & 50045 & 332 & 6 & 21 & 22 \\
\hline GMC & Yukon & 37340 & 320 & 2 & 14 & 20 \\
\hline Honda & Civic Hybrid & 22600 & 110 & 10 & 40 & 45 \\
\hline Honda & Civic & 17560 & 140 & 8 & 25 & 36 \\
\hline Lexus & GS 450h Hybrid & 55800 & 340 & 7 & 22 & 25 \\
\hline Lexus & GS 460 & 53020 & 342 & 6 & 17 & 24 \\
\hline Lexus & RX 400h Hybrid & 41580 & 268 & 7 & 27 & 24 \\
\hline Lexus & $\mathrm{RX} 350$ & 37400 & 270 & 6 & 18 & 23 \\
\hline Mazda & Tribute Hybrid & 25485 & 133 & 8 & 34 & 30 \\
\hline Mazda & Tribute & 21325 & 153 & 6 & 20 & 26 \\
\hline Mercury & Mariner Hybrid & 28150 & 155 & 8 & 34 & 30 \\
\hline Mercury & Mariner & 21540 & 153 & 6 & 20 & 26 \\
\hline Nissan & Altima Hybrid & 25480 & 158 & 9 & 35 & 33 \\
\hline Nissan & Altima & 20970 & 175 & 8 & 23 & 31 \\
\hline Saturn & Aura Hybrid & 23900 & 164 & 8 & 24 & 32 \\
\hline Saturn & Aura & 20405 & 169 & 7 & 22 & 30 \\
\hline Saturn & VUE Hybrid & 25645 & 172 & 8 & 25 & 32 \\
\hline Saturn & VUE & 21525 & 169 & 5 & 19 & 26 \\
\hline Toyota & Camry Hybrid & 25200 & 187 & 9 & 33 & 34 \\
\hline Toyota & Camry & 21075 & 158 & 7 & 21 & 31 \\
\hline Toyota & Highlander Hybrid & 34200 & 270 & 8 & 27 & 25 \\
\hline Toyota & Highlander & 27500 & 270 & 5 & 18 & 24 \\
\hline Toyota & Prius (Hybrid) & 21500 & 110 & 10 & 48 & 45 \\
\hline Toyota & Corolla & 15205 & 126 & 8 & 26 & 35 \\
\hline
\end{tabular}


Table 2: Prices Over Time

\begin{tabular}{lllll}
\hline Vehicle & Make & $\underline{\mathbf{2 0 0 8}}$ & $\frac{\mathbf{2 0 0 7}}{20726}$ & $\frac{\mathbf{2 0 0 6}}{19830}$ \\
Ford & Escape Hybrid & 27445 & 13608 & 12283 \\
& Escape & 20140 & 32974 & 31264 \\
Lexus & & 41580 & 29184 & 25818 \\
Lexus & RX 400h Hybrid & 37400 & 22406 & 20845 \\
Mercury & RX 350 & 28150 & 16641 & 14644 \\
Mercury & Mariner Hybrid & 21540 & 24904 & 21840 \\
Toyota & Mariner & 34200 & 18364 & 16262 \\
Toyota & Highlander Hybrid & 27500 & 21017 & 19892 \\
Toyota & Highlander & 21500 & 12888 & 11538 \\
Toyota & Prius (Hybrid) & & & \\
\hline
\end{tabular}

\title{
INSTRUCTORS' NOTES FOR “ARE HYBRID CARS A GOOD BUY?”
}

\begin{abstract}
This case examines the benefits and costs of buying a hybrid car. Students examine the car purchase decision along with depreciation rates and the long-term value of hybrid cars, while they calculate the benefits and costs of the various hybrid vehicles and their comparable sister cars. Secondary issues include an examination of the trade-in value for non-hybrid cars and the horsepower and greenhouse gas emission differences between hybrid and their sister cars. Furthermore, students will examine whether or not the federal tax credit for hybrids should be reinstated.
\end{abstract}

\section{RECOMMENDATIONS FOR TEACHING APPROACHES}

1. Using the figures given in the case, calculate breakeven number of years, also called the payback period, for each vehicle.

Table 1 (located at the end of the instructor notes) shows the breakeven years for the vehicles at three different gas prices. At higher gas prices, the breakeven number of years falls. None of the vehicles have a breakeven less than three years. The Mazda Tribute and the Lexus GS 450h have the lowest breakevens or payback period at 3.2 years when gasoline prices are at $\$ 4.50$ per gallon.

A few things are clear from the table. First, the hybrids sell at a large premium to their sister vehicles. While some of the hybrids have more standard options, after adding in $\$ 1,000$ for the differences, the premium is still large. Second, the gas mileage savings is not even. Of the fifteen pairs of vehicles, only five, or one-third, save more than 200 gallons a year. Two vehicles, the Chevrolet Malibu and the Saturn Aura don't even save fifty gallons in a year.

Breakeven was calculated at 15,000 miles a year. At higher annual mileage, the cost saving from the fuel economy increases. Additionally, breakeven is lower at higher gasoline prices. Thus, taking an extreme example of 30,000 miles and gasoline at $\$ 4.50$ a gallon, nine hybrid vehicles reach breakeven in under three years: Honda Civic (2.75 years), Lexus GS 450h (1.6 years), Lexus RX 400h (1.9 years), Mazda Tribute (1.6 years), Mercury Mariner (2.8 years), Nissan Altima (2.65 years), Saturn VUE (2.25 years), Toyota Camry (2.1 years), and the Prius (2.95 years). Thus, at the extreme scenario, the Lexus and the Tribute have the shortest payback periods, while the Prius has the longest. This clearly demonstrates that for the current hybrid price to be worth it, a person must drive a lot and gasoline prices must be high. 
A logical next step is to determine the reason why the six cars don't reach breakeven under extreme conditions. The Chevrolet Malibu and Saturn Aura hybrids do not have enough of a gain in fuel economy (only 2 $\mathrm{mpg}$ ) to offset the premium. The Chevrolet Tahoe sells at a huge premium. This is one vehicle where the option differences might be more than $\$ 1,000$. However, it is unlikely that they are $\$ 10,000$ more, which is the approximate amount the premium would have to be decreased to make the vehicle breakeven in three years at 30,000 miles and $\$ 4.50$ a gallon. The GMC Yukon is the same reasoning as the Tahoe. Its premium would need to be lowered by $\$ 8,500$ for it to break even. The Ford Escape and the Toyota Highlander are close to breakeven, but not quite under three years. Both vehicles gain in fuel economy, but not enough to offset the price premium.

2. After examining the horsepower and greenhouse score for each vehicle, what conclusions can you draw?

Comparing the horsepower is difficult because there are many other factors that matter in determining the power and handling of a vehicle. However, while most of the vehicles do have a decrease in horsepower, the decrease is not huge. On the vehicle pairs where the difference is large, the fuel economy generally is much better. For example, the Honda Civic has a $21 \%$ decrease in horsepower (110/140) and a $45 \%$ increase in fuel economy (41.7/28.7). While not as dramatic as one might think, there is a trade-off between horsepower and fuel efficiency.

Regarding the greenhouse score, all of the hybrids have better scores than their sister cars. The Honda Civic and the Toyota Prius have a perfect score of 10. The larger SUVs, Chevy Tahoe and the GMC Yukon, even though they are hybrids, only have a score of 6 . Interestingly, the cars with the highest greenhouse number do not have the highest premium. However, they do have the highest fuel economy at over $40 \mathrm{mpg}$.

3. Do hybrids depreciate slower than comparable vehicles?

The table below shows the one-year and two-year rates of deprecation for the five vehicles that have been made for three years. The hybrids clearly do not depreciate as fast. Like all cars, the vehicles depreciate quickly after the first year. This is interesting because it is believed that there is a huge demand for used hybrids. While the vehicles don't depreciate as quickly, they still depreciate, indicating that buyers of used hybrids are not willing to pay the price premium. A quick comparison of the 2007 hybrid price and the 2008 non-hybrid price shows that they are closer in price. Thus, used car buyers are not willing to pay the hybrid premium, but they do recognize the value of the hybrid and price it close to its sister car that is new.

A glaring exception to this relationship is the Toyota Prius. The Prius has very little depreciation. The reason is that the number of Priuses manufactured is low and it is held low to create the shortage, subsequent media coverage and corresponding price premium. Less than 50,000 new Priuses were available in 2007. If production were to increase, the rate of depreciation would increase.

Instructor's Notes - Table 2: Depreciation Rates

\begin{tabular}{|c|c|c|c|c|c|c|}
\hline Vehicle & Make & 2008 & 2007 & $\underline{2006}$ & 07 to 08 & 06 to 08 \\
\hline$\overline{\text { Ford }}$ & $\overline{\text { Escape Hybrid }}$ & $\overline{27445}$ & $\overline{20726}$ & $\overline{19830}$ & $\overline{-24.48 \%}$ & $\overline{-27.75 \%}$ \\
\hline Ford & Escape & 20140 & 13608 & 12283 & $-32.43 \%$ & $-39.01 \%$ \\
\hline Lexus & RX 400h Hybrid & 41580 & 32974 & 31264 & $-20.70 \%$ & $-24.81 \%$ \\
\hline Lexus & RX 350 & 37400 & 29184 & 25818 & $-21.97 \%$ & $-30.97 \%$ \\
\hline Mercury & Mariner Hybrid & 28150 & 22406 & 20845 & $-20.40 \%$ & $-25.95 \%$ \\
\hline Mercury & Mariner & 21540 & 16641 & 14644 & $-22.74 \%$ & $-32.01 \%$ \\
\hline Toyota & Highlander Hybrid & 34200 & 24904 & 21840 & $-27.18 \%$ & $-36.14 \%$ \\
\hline Toyota & Highlander & 27500 & 18364 & 16262 & $-33.22 \%$ & $-40.87 \%$ \\
\hline Toyota & Prius (Hybrid) & 21500 & 21017 & 19892 & $-2.25 \%$ & $-7.48 \%$ \\
\hline Toyota & Corolla & 15205 & 12888 & 11538 & $-15.24 \%$ & $-24.12 \%$ \\
\hline
\end{tabular}


4. Should Matt make a loan to Kurt to expand his lot for hybrids? What issues must Kurt address?

There is a demand for hybrids and the vehicles do hold their value. However, Kurt needs to be sure that hybrids will continue to be in demand in the upcoming years. As discussed in question \#1, for hybrids to make sense at their current prices, the owner has to drive a lot and gasoline prices must be high. In addition, since hybrids make more sense for city driving with a lot of stopping and starting, hybrids are not as good of a choice in rural areas or for people who do a lot of highway driving. One needs a city driver who is driving a lot each day in heavy traffic. As more cities push for mass transit, this will decrease the benefit of hybrids for all but the most extreme driver. Certainly, the taxi market could be a customer base. Of course, the vehicle needs to be large enough to hold passengers and their belongings, which some of the more fuel-efficient hybrids are not.

Kurt must also decide if he does want to take the trade-ins. The trade-ins will most likely be the larger vehicles that are not fuel-efficient. If Kurt takes the trade-ins, he must identify who will be the buyers of these vehicles and the price they are willing to pay. Kurt needs to balance how much he is willing to give for a trade-in and then get customers to buy hybrids from him at the price he will be able to resell the trade-in to a different customer. Thus, there is a trade-off with trade-ins for hybrids.

5. Should the federal government renew the tax rebates for hybrid cars?

The answers from students will depend on several factors. If the rebates are renewed, certainly more hybrids will be sold. However, since the hybrids are already selling at a premium, the rebate is really just returning some of the premium to the buyer. Unless supply increases, the increase in quantity demanded will further increase the premium. Students need to decide if the government should reallocate funds away from things such as research and development on alternative energies to helping some people buy a new car. Rebates are used to change demand patterns by lowering prices. If the premium just increases to offset the premium, the rebate loses its initial value.

6. Is Matt's concern that hybrids will be replaced by any new technologies justified?

All of the vehicle manufacturers are working on better hybrids or better technology to replace hybrids. Certainly, any new gains in technology will make the old technology worthless. However, currently there is no time frame for when the alternative technologies will arrive on the market. Until then, the hybrid is the best option. A concern would be that once a new and better technology arrives on the market, the value of the hybrids will fall quickly. Technology is always changing and there is profit to be made in selling hybrids until the alternatives arrive. This is a common situation in business. Every year brings a slightly better television and computer. Of course, because of the size of the expenditure of a car, Matt needs to decide if the demand for hybrids will maintain and grow in the new few years. Part of that answer depends upon gasoline prices. As long as prices remain high, there will be demand for fuel-efficient vehicles. Additionally, if Matt decides not to give the loan to Kurt, he will lose the customer and that revenue. Perhaps Kurt will expand again when the next technology arrives.

7. Should Matt and Chelsea buy a new hybrid?

While there is no right or wrong answer, most students would encourage Matt and Chelsea to wait. The couple is trying to save money and the premium on the hybrid would be too much right now, especially considering their savings goals. Chelsea does need to find a way to reduce her gasoline expenditures. Perhaps, the company can provide her with some level of reimbursement or she can try to find ways to limit the number of trips she takes. In an extreme solution, Chelsea could look for another job that doesn't require so much driving.

Matt and Chelsea could consider buying a used hybrid. If they were going to buy a new-to-them vehicle, a used hybrid could be a good choice. Based on the fuel economy, the 2007 Honda Civic is a fine option. For cars that have been around at least three years, the Ford Escape and the Toyota Prius are good choices. Of course, used Priuses are hard to find. Overall, Matt and Chelsea need to weigh the additional cost of a hybrid with the fuel economy and decide if it is worth it. 


\section{AUTHOR INFORMATION}

Dr. Anne Macy is the Gene Edwards Professor of Finance and Director of the College of Business StudentManaged Investment Fund at West Texas A\&M University. She is an active member of the Texas Council on Economic Education and conducts finance and economic education seminars for the Federal Reserve Bank of Dallas. Macy also is an adjunct professor for the Pacific Coast Bank School at the University of Washington in Seattle. Macy has published over 15 research articles and cases. Her Ph.D. is from Texas Tech University.

\section{REFERENCES}

1. Bradford, Stacey (2003). Are hybrid cars worth it? Smartmoney, November 28. Retrieved June 4, 2008, from http://www.smartmoney.com/consumer/index.cfm?story=20031126

2. CNN website (2006). Hybrid cars will pay for themselves over time. August 22. Retrieved June 4, 2008, from http://www.cnn.com/2006/AUTOS/08/22/bc.autos.hybrids.reut/index.html

3. Department of Energy and the Environmental Protection Agency. Statistics on fuel economy. Retrieved June 4, 2008, from http://www.fueleconomy.gov/

4. Edmunds. Car prices. Retrieved June 4, 2008, from http://www.edmunds.com/ --- (2006). Do hybrids make financial sense yet? October 19. Retrieved June 4, 2008, from http://www.edmunds.com/advice/fueleconomy/articles/116513/article.html

5. Greenhouse Gas Guide. Environmental Protection Agency. Retrieved June 4, 2008, from http://www.epa.gov/greenvehicles/Index.do

6. Radowitz, Bernd (2007). Hybrid cars still seen distant from economic break-even. Marketwatch website, October 11. Retrieved June 4, 2008, from http://www.marketwatch.com/news/story/hybrid-cars-still-seendistant/story.aspx?guid=\%7B24DEC4D6-ACA1-4FDD-A0B6-6C38AD5F2E6C\%7D

7. Valdes-Dapena, Peter (2006). Hybrids: Seven worries, seven answers. CNN Money website, September 27. Retrieved June 4, 2008, from http://money.cnn.com/2006/09/27/autos/tipsandadvice/hybrid_worries/index.htm

8. Weston, Liz Pulliam (2008). The costly secret of hybrid cars. MSN Money website. Retrieved June 4, 2008, from http://articles.moneycentral.msn.com/SavingandDebt/SaveonaCar/TheCostlySecretsOfHybridCars.aspx 
Instructor's Notes - Table 1 for Question \#1: Breakeven years

\begin{tabular}{|c|c|c|c|c|c|c|c|c|c|c|c|}
\hline Vehicle & Make & Base price & City MPG & $\begin{array}{l}\text { Highway } \\
\text { MPG }\end{array}$ & $\begin{array}{c}\text { Average } \\
\text { MPG }\end{array}$ & $\begin{array}{l}\text { Gallons for } \\
15,000 \text { miles }\end{array}$ & $\begin{array}{c}\text { Gallon } \\
\text { Savings }\end{array}$ & $\begin{array}{c}\text { Price } \\
\text { Premium }\end{array}$ & $\begin{array}{l}\text { Breakeve } \\
\$ 2.50 \text { per } \\
\text { gallon }\end{array}$ & $\begin{array}{l}\text { Years/ Payl } \\
\$ 3.50 \text { per } \\
\text { gallon }\end{array}$ & $\begin{array}{c}\text { ck Period } \\
\$ 4.50 \text { per } \\
\text { gallon }\end{array}$ \\
\hline Chevrolet & Malibu Hybrid & 23640 & 24 & 32 & 26.7 & 562.5 & 45.6 & 2740 & 24.0 & 17.2 & 13.4 \\
\hline Chevrolet & Malibu & 20900 & 22 & 30 & 24.7 & 608.1 & & & & & \\
\hline Chevrolet & Tahoe Hybrid & 49590 & 21 & 22 & 21.3 & 703.1 & 254.3 & 13960 & 22.0 & 15.7 & 12.2 \\
\hline Chevrolet & Tahoe & 35630 & 14 & 19 & 15.7 & 957.4 & & & & & \\
\hline Ford & Escape Hybrid & 27445 & 34 & 30 & 32.7 & 459.2 & 222.6 & 6305 & 11.3 & 8.1 & 6.3 \\
\hline Ford & Escape & 21140 & 20 & 26 & 22.0 & 681.8 & & & & & \\
\hline GMC & Yukon Hybrid & 50045 & 21 & 22 & 21.3 & 703.1 & 234.4 & 11705 & 20.0 & 14.3 & 11.1 \\
\hline GMC & Yukon & 38340 & 14 & 20 & 16.0 & 937.5 & & & & & \\
\hline Honda & Civic Hybrid & 22600 & 40 & 45 & 41.7 & 360.0 & 163.3 & 4040 & 9.9 & 7.1 & 5.5 \\
\hline Honda & Civic & 18560 & 25 & 36 & 28.7 & 523.3 & & & & & \\
\hline Lexus & GS 450h Hybrid & 55800 & 22 & 25 & 23.0 & 652.2 & 123.7 & 1780 & 5.8 & 4.1 & 3.2 \\
\hline Lexus & GS 460 & 54020 & 17 & 24 & 19.3 & 775.9 & & & & & \\
\hline Lexus & RX 400h Hybrid & 41580 & 27 & 24 & 26.0 & 576.9 & 185.8 & 3180 & 6.8 & 4.9 & 3.8 \\
\hline Lexus & RX 350 & 38400 & 18 & 23 & 19.7 & 762.7 & & & & & \\
\hline Mazda & Tribute Hybrid & 25485 & 34 & 30 & 32.7 & 459.2 & 222.6 & 3160 & 5.7 & 4.1 & 3.2 \\
\hline Mazda & Tribute & 22325 & 20 & 26 & 22.0 & 681.8 & & & & & \\
\hline Mercury & Mariner Hybrid & 28150 & 34 & 30 & 32.7 & 459.2 & 222.6 & 5610 & 10.1 & 7.2 & 5.6 \\
\hline Mercury & Mariner & 22540 & 20 & 26 & 22.0 & 681.8 & & & & & \\
\hline Nissan & Altima Hybrid & 25480 & 35 & 33 & 34.3 & 436.9 & 147.5 & 3510 & 9.5 & 6.8 & 5.3 \\
\hline Nissan & Altima & 21970 & 23 & 31 & 25.7 & 584.4 & & & & & \\
\hline Saturn & Aura Hybrid & 23900 & 24 & 32 & 26.7 & 562.5 & 45.6 & 2495 & 21.9 & 15.6 & 12.2 \\
\hline Saturn & Aura & 21405 & 22 & 30 & 24.7 & 608.1 & & & & & \\
\hline Saturn & VUE Hybrid & 25645 & 25 & 32 & 27.3 & 548.8 & 154.3 & 3120 & 8.1 & 5.8 & 4.5 \\
\hline Saturn & VUE & 22525 & 19 & 26 & 21.3 & 703.1 & & & & & \\
\hline Toyota & Camry Hybrid & 25200 & 33 & 34 & 33.3 & 450.0 & 166.4 & 3125 & 7.5 & 5.4 & 4.2 \\
\hline Toyota & Camry & 22075 & 21 & 31 & 24.3 & 616.4 & & & & & \\
\hline & Highlander & & & & & & & & & & \\
\hline Toyota & Hybrid & 34200 & 27 & 25 & 26.3 & 569.6 & 180.4 & 5700 & 12.6 & 9.0 & 7.0 \\
\hline Toyota & Highlander & 28500 & 18 & 24 & 20.0 & 750.0 & & & & & \\
\hline Toyota & Prius (Hybrid) & 21500 & 48 & 45 & 47.0 & 319.1 & 198.1 & 5295 & 10.7 & 7.6 & 5.9 \\
\hline Toyota & Corolla & 16205 & 26 & 35 & 29.0 & 517.2 & & & & & \\
\hline
\end{tabular}


NOTES 